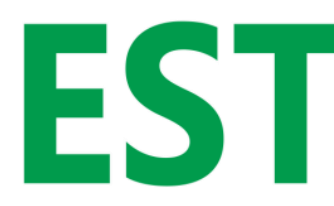

Journal of Educational Science and Technology

Volume 5 Number 2 August 2019 page 166-175

p-ISSN:2460-1497 and e-ISSN: 2477-3840

DOI: https://doi.org/10.26858/est.v5i2.9670

\title{
Increased Behavior of Students' Attitudes to Cultural Values Using the Inquiry Learning Model Assisted Ethno constructivism
}

\author{
Syahrial $^{1}$, Asrial ${ }^{2 *}$, Dwi Agus Kurniawan ${ }^{3}$, Putut Nugroho ${ }^{4}$, Retno Septiasari ${ }^{5}$, Reza Aditya \\ Pratama $^{6}$, Rahmat Perdana ${ }^{7}$ \\ ${ }^{1}$ Language and Linguistic Field, Universitas Jambi, Indonesia \\ Email: syahrial.karea@gmail.com \\ ${ }^{2}$ Chemistry Education, Universitas Jambi, Indonesia \\ Email: porigih@gmail.com \\ ${ }^{3}$ Physics Education, Universitas Jambi, Indonesia \\ Email: dwiagus.k@unja.ac.id \\ ${ }^{4}$ Science Education, Universitas Jambi, Indonesia \\ Email: putunugroho@gmail.com \\ ${ }^{5}$ Science Education, Universitas Jambi, Indonesia \\ Email: retnoseptiasari@gmail.com \\ ${ }^{6}$ Science Education, Universitas Jambi, Indonesia \\ Email: masrezaaditya17@gmail.com \\ ${ }^{7}$ Physics Education, Universitas Jambi, Indonesia \\ Email: rahmat260997@gmail.com
}

(Received: June-2019; Reviewed: July-2019; Accepted: August-2019; Published: August-2019)

\begin{abstract}
The purpose of theresearch is student attitudes toward cultural values are needed in 21st century learning. Research with a focus on improving student attitudes towards cultural values using inquiry-based approaches. Therefore, this quasi-experimental quantitative research aims to improve student attitudes to the cultural values of elementary school teacher education students with an inquiry model assisted by the ethnoconstructivism module. Methodology uses a quantitative design of quasi-experimental pretest-posttest non-equivalent control group design. Where the number of all samples from this study were 86 elementary school teacher education students in Universitas Jambi taken by purposive sampling technique. The experimental group $(n=43)$ was taught with the inquiry learning model assisted by the ethnoconstructivism module, while the control group $(n=43)$ was taught using traditional teaching modul. The data were then analyzed using the SPSS 21 application to find descriptive statistics and inferential static. Resulth:There was a significant difference in the attitude of students between the control class and the experimental class. It was found that using ethnoconstructivism inquiry models obtained differences with t-test values 18,473 on student attitudes. It can be underlined that the inquiry model with ethnoconstructivism has a significant influence on student attitudes towards cultural values compared to conventional groups.
\end{abstract}

Keywords: Behavior; Inquiry; Attitude; Etno Constructivism; Cultural Values.

\section{INTRODUCTION}

The development of science and technology has led to a process of change in all aspects of life, including the world of education. The need for services and opportunities for improving learning for students is the driver of the emergence of education reform. Therefore, education reform must always be carried out by pursuing a learning process that is in line with the times by utilizing Information and Communication Technology (ICT). The use of 
information and communication technology in learning can support and develop student skills both student cognitive, affective and social skills, even higher skills (Hidayat, Kusumaningrum \& Mardin, 2017). So that the use of information technology in the learning process has become a necessity as well as a demand. The Law of the Republic of Indonesia Number 20 of 2003 concerning the national education system states that the learning process is a process of interaction between students and educators and learning resources in the learning environment. Kyriakides, \& Creemers, (2008); Aktekin, (2019), the teaching and learning process is a three-way relationship between lecturers, materials used and students. Which can later affect in terms of the psychology of the student.

The inquiry learning model can provide many benefits, one in terms of psychology. The psychological aspects contained in the inquiry model provide many advantages because it allows students to use all their potential, especially their mental processes, to find their own concepts plus other mental processes that give adult characteristics or characteristics of a humanist, so students can find self-concept, critical and creative. Attitudes can be defined as a tendency to provide learned, consistent, positive or negative reactions to an object (Astalini et al, 2019; Bulunuz, 2015). Astalini et al (2019) define attitude as part of individual personality influenced by relationship behavior with it. Attitudes can also be defined as a tendency to act against people, things, events, or ideas. Attitudes seem unconscious, sustainable and closely related to opinion. Attitudes are formed as a result of the learning experience. Seferoğlu (2004); Darmaji (2018) Attitudes are related to overcoming and managing emotions that occur during the learning process, and they play an important role in directing human behavior. Therefore, one that can influence student behavior during the learning process can also be influenced by how students' attitudes toward subjects.

The attitude of students in learning cultural values is based on the feelings or interests of students in learning these cultural values (Esther Agunbiade, 2017). In addition to feeling happy students can also emulate a humanist who is very skilled in culture and find new things. Instead of assuming that the humanist is ugly, dull, even there is no time for his family (Christidou, 2011). In addition, if students behave negatively towards cultural values, the student has no interest in learning cultural values. Positive attitudes and interests in the subject of cultural values will lead to students' future careers that will increase (Welch, 2010). One that influences students in learning cultural values is the lack of interest from students themselves. Therefore, to improve students in learning cultural values can use inquiry-based learning.

Inquiry-based learning can influence a person's attitude in learning. This can be shown from the attitudes and behavior of students that reflect low achievement motivation, values of responsibility, independence, honesty, discipline, perseverance and low selfconfidence. Class assignments are collected not on time, assignments are collected in a minimum, absent from entering college without information, and even doing cheating when taking the final semester exam. Because if students have a negative attitude to cultural values, they will also have a negative attitude to their teacher (Guido, 2013; Astalini et al, 2019; Kurniawan, Astalini, \& Anggraini, 2018). Therefore, the teacher must know how the attitudes of students that occur during the learning process because by knowing the attitudes of students, teachers can improve the design of learning in the classroom, according to the abilities possessed by students. One of the attitudes of students, which needs to be considered by a teacher is a scientific attitude. Trumper (2006) scientific attitudes greatly influence the learning process involving student attitudes. Students who have high scientific attitudes will help the learning process improve. This is because scientific attitudes can shape students thinking creatively and critically.

Efforts to improve attitudes to the cultural values of elementary school teacher education students are needed to be creative and innovative learning. This learning must be done by lecturers as an effort to have students who are active and creative in solving problems both in lectures and in daily life. Because the teacher's task is to encourage students to do something. The teacher comes to class with problems to solve by students, then they are guided to find the best way to solve the problem. The level of success of teaching staff in teaching is seen from the success of their students, so it is said that great educators are educators who can inspire students (Sofanudin, 2016; Cetin, Mirasyedioglu, \& Cakiroglu, 2019). According 
to Kunnari (2014); Aybek, \& Aslan, (2016) educational innovations are ideas, goods, methods, which are perceived or observed as new things for the results of a person or group of people (society), either in the form of inversions (new discoveries) or inventions (new discoveries), which used to achieve educational goals or to complete. The effort is to monitor and control learning independently through a variety of positive, adaptive, or positive cognitive-behavioral management strategies for learning and achieving learning goals. At present students are required to access knowledge and configure it independently (Tezer, Kan \& Bas, 2019). Rabgay (2018) argues that lecturers need to use innovative and interactive teaching techniques to bring improvements in the teaching process. In order to improve the quality of education to produce graduates who are creative, and able to face life in the future, innovation is needed, one of which is by using the inquiry learning model.

Inquiry model is a model that is very suitable for use in learning activities. According to (Gillet, 2017) Inquiry-based learning is a teaching method and educational philosophy were problem-solving in learning is by participating in or involved in learning. Students are directed to carry out their own learning activities such as formulating hypotheses, designing experiments, analyzing experiments, collecting data so students can build their attitudes. Simsek \& Kabapinar (2010); Cetin, Mirasyedioglu, \& Cakiroglu, (2019) argue that inquiry-based learning is effective in helping students develop their skills and attitudes. Wulandari (2013); Syahrin et al (2019) also said that "Inquiry-based learning activities are the center of learning where students are involved in problem formulation, making hypotheses, collecting and analyzing data, and drawing conclusions from problems". Inquiry-based learning is a teaching method and educational philosophy were problem-solving in learning is by participating in or involved in learning. This inquiry learning model aims to provide a way for students to build intellectual skills related to thought processes. Students work independently and in small groups to gain knowledge through their involvement (Gillette, 2017; Aktekin, 2019). Therefore the inquiry learning model has a good impact on learning.

The results of the initial study conducted that the cultural attitudes are still low held by elementary school teacher education students at the Universitas Jambi, this can be evidenced from the results of interviews conducted by students, the student said that he did not know the cultural values that he had around him because neither introduced by the environment nor his parents. This is reinforced by statements from lecturers who teach that in primary school teacher education has not integrated learning with the culture that is around. Therefore, the purpose of this study was to see whether the inquiry learning model was assisted by ethnoconstructivism modules with traditional print teaching materials used in lectures could improve student attitudes in learning.

\section{METHOD}

The research design used by the researcher is a quantitative research type quasiexperimental design using pretest and posttest non-equivalent control group design. It was conducted to investigate causal hypotheses about causes that could be manipulated by comparing one or more experimental groups treated with one untreated comparison group (Creswell, 2012). The design of this study was applied because it was in accordance with the purpose of the study, where the aim was to find out whether there were differences between attitudes on cultural values of students using the inquiry learning model assisted by the ethnoconstructivism module with traditional print teaching materials used in lectures. This research uses descriptive statistics in the form of mean, min and max and uses inferential statistics. The inferential statistics used are independent sample t-test.

Tabel 1. Pretest-Posttest Non-Equivalent Control Group Design

\begin{tabular}{llll}
\hline Group & Pretest & Treatment & Posttest \\
\hline Experimental & $\mathrm{O}_{1}$ & Inquiry Learning Model Assisted By The Ethnoconstructivism Module & $\mathrm{O}_{1}$ \\
Control & $\mathrm{O}_{2}$ & Traditional learning module & $\mathrm{O}_{2}$ \\
\hline
\end{tabular}

This research was located in primary school teacher education with a total of $868^{\text {th }}$ semester students in education at the Universitas Jambi elementary school teacher, Jambi 
Province. In the experimental class, there were 43 students and in the control class, there were 43 students. In the experimental class using the inquiry learning model assisted by the ethnoconstructivism module and in the control class using traditional print teaching materials used in lectures. The sample collection technique uses purposive sampling method. Purposive sampling is a sampling technique based on the criteria of the researcher (Kerlinger, 2014). The procedure for collecting data for referring to Creswell (2012), is explained in the figure below:

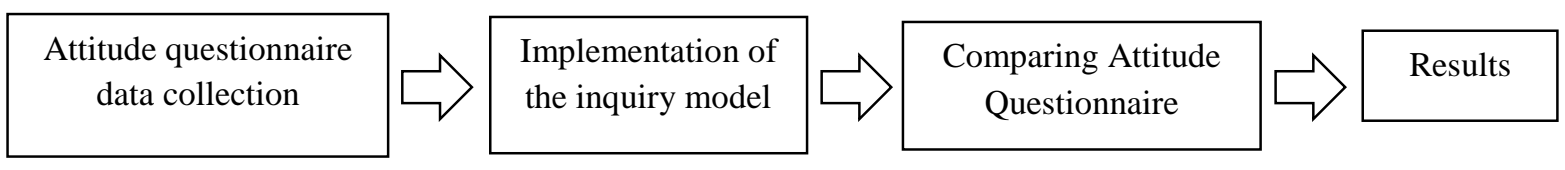

Figure 1. Research Procedure

Based on the picture above, it can be seen that the first activity that must be carried out in the process of data collection, namely the distribution of questionnaires to students of $8^{\text {th }}$ semester elementary school teacher education to see its initial value. Then giving action only to the experimental class using the inquiry learning model assisted by ethnoconstructivism, while for the control class traditional teaching materials were provided. After that, see the results of attitudes on student cultural values after being given an inquiry model with those not using the inquiry model. The instrument used was a questionnaire. Cohen, Manion \& Morrison (2007), Questionnaires are lists of questions given to other people who are willing to answer (respondent) according to the user's request. In this study, this study used a questionnaire and semi-open interview instrument, in this study using a 5 (five) Likert scale for positive statements Strongly Disagree having a score of 1 , Disagree having a score of 2 , Neutral having a score of 3, Agree having a score 4 and Strongly Agree 5. For negative statements Strongly Disagree has a score of 5, Disagree has a score of 4 , Neutral has a score of 3 , Agree has a score of 2 and Strongly Agree has a score of 1). The attitude of students towards cultural values, namely interest in increasing the time to learn cultural values, cultural normality, and interest in a career in the cultural field.

Below is a category of questionnaire cultural values, among others, very good, good, sufficient, not good, and not very good, as in table 2 below:

Table 2. Categories of attitudes of elementary school education students

\begin{tabular}{|c|c|c|c|}
\hline \multirow[b]{2}{*}{ Category } & \multicolumn{3}{|c|}{ Interval } \\
\hline & $\begin{array}{l}\text { Interest Increased } \\
\text { Learning Time in } \\
\text { Cultural Values }\end{array}$ & Cultural Normality & $\begin{array}{l}\text { Interest Career in the } \\
\text { field of culture }\end{array}$ \\
\hline Very Not Good & $8.0-14.4$ & $5.0-8.0$ & $10-17$ \\
\hline Not Good & $14.4-20.9$ & $9.0-12.0$ & $18-25$ \\
\hline Enough & $30.0-36.4$ & $13.0-16.0$ & $26-33$ \\
\hline Good & $36.5-42.9$ & $17.0-20.0$ & $34-41$ \\
\hline Very Good & $43.0-49.4$ & $21.0-25.0$ & $42-50$ \\
\hline
\end{tabular}

All data obtained from attitude questionnaires on student values in both the control class and experimental class were collected and then calculated and assisted with the SPSS 21 application. Descriptive statistics were given to calculate the frequency, percentage, mean, min, and max of sample (Creswell, 2012) in the control and experimental groups. In this study, quantitative data were analyzed using parametric statistics of the independent sample t-test. Independent sample t-test was conducted to examine the effect of attitudes on cultural values and critical thinking of students. This study uses SPSS 21 at the significance level of 0.025 . And followed by interviews that are used to strengthen the results of quantitative data. Followed by interviews intended to strengthen the results of quantitative data. The steps in the interview can be seen as follows : (1) to calculate frequencies such as ideas, themes, pieces of data and words. (2) pay attention to patterns and themes. (3) try to make good data, using intuition to reach conclusion. (4) is a group set items into categories, types, 
behavior, and classification? (5) makes a metaphor that uses figurative language and connotative rather than literal and denotative language, animates data, thereby reducing data, making patterns, aligning data, linking data with theory. (6) separate variables to decipher, differentiate and 'unpack' ideas, ie move from drive to integration and obfuscate data. (7) surrendered specifically into the general, carrying a large number of variables under a small number of (frequently) unobserved hypothetical variables. (8) identifies and records relationships between variables. (9) finds an intervening variable: looks for another variable that seems to 'block' calculations for what is expected to be a strong relationship between variables. (10) building logical chain of evidence: noting causality and making conclusions. (11) Creating conceptual/theoretical coherence: moving from metaphor to construct to tories to explain phenomena (Cohen, Manion \& Morrison, 2007).

\section{RESULTS AND DISCUSS}

\section{Results}

The research findings are explained in this section. Category results, Mean, Min, Max, and Percentage, both pretest or posttest, to show the impact of the inquiry model assisted by ethnconstructivism modules in primary schools are presented as follows (see Table 3-4).

Table 3. Gaps in Attitude Scores in Pretest Cultural Values between Experimental Classes and Control Classes

\begin{tabular}{llllllll}
\hline Indikator & Groups & Category & Mean & Min & Max & N & \% \\
\hline Interest Increased Learning & Experiment & Enough & 28.3 & 11 & 45 & 43 & 43.6 \\
Time in Cultural Values & Control & Enough & 27.9 & 10 & 43 & 43 & 32.7 \\
& Experiment & Good & 35.4 & 7 & 23 & 43 & 43.8 \\
Cultural Normality & Control & Enough & 29.6 & 8 & 22 & 43 & 34.2 \\
\multirow{2}{*}{$\begin{array}{l}\text { Interest Career in the field of } \\
\text { culture }\end{array}$} & Experiment & Enough & 32.4 & 15 & 46 & 43 & 41.2 \\
& Control & Enough & 30.9 & 9 & 44 & 43 & 39.5 \\
\hline
\end{tabular}

Based on the average rank and categories shown in Table 3, the pretest scores of the experimental group students were slightly higher in the indicator of humanity normality, namely $43.8 \%(\mathrm{M}=35.4)$ and the lowest Interest Career in the field of culture $41.2 \%$ (M $=30.9$ ). Control group students were slightly higher in terms of interest in increasing time on cultural values, namely $43.6 \%(\mathrm{M}=28.3)$ and lowest Interest increased learning time in cultural values $32.7 \%(\mathrm{M}=27.9)$. This shows that before treatment, all students have the same attitude in cultural values.

Table 4. Gaps in Attitude Scores on Posttest Cultural Values between Experimental Classes and Control Classes

\begin{tabular}{|c|c|c|c|c|c|c|c|}
\hline Indikator & Groups & Category & Mean & Min & $\operatorname{Max}$ & $\mathbf{n}$ & $\%$ \\
\hline \multirow{2}{*}{$\begin{array}{l}\text { Interest Increased Learning Time } \\
\text { in Cultural Values }\end{array}$} & Experiment & Baik & 39.5 & 11 & 47 & 43 & 47.3 \\
\hline & Control & Cukup & 32.8 & 15 & 44 & 43 & 32.6 \\
\hline \multirow{2}{*}{ Cultural Normality } & Experiment & Baik & 39.5 & 6 & 24 & 43 & 50.6 \\
\hline & Control & Cukup & 31.2 & 7 & 23 & 43 & 39.3 \\
\hline $\begin{array}{l}\text { Interest Career in the field of } \\
\text { culture }\end{array}$ & $\begin{array}{l}\text { Experiment } \\
\text { Control }\end{array}$ & $\begin{array}{l}\text { Baik } \\
\text { Cukup }\end{array}$ & $\begin{array}{l}40.8 \\
34.3\end{array}$ & $\begin{array}{l}18 \\
12\end{array}$ & $\begin{array}{l}47 \\
43\end{array}$ & $\begin{array}{l}43 \\
43\end{array}$ & $\begin{array}{l}47.1 \\
44.6\end{array}$ \\
\hline
\end{tabular}

According to the average ranking and category presented in Table 4, it shows that the experimental group students were more dominant in all indicators compared to the control group students. This confirms that the inquiry model implementation assisted by the ethnoconstructivism module has a significant impact on student attitudes. In addition, the experimental group students received the highest average rating in the Cultural Normality of 
$50.6 \%(\mathrm{M}=39.5)$ and the lowest in Interest Career in the field of culture $47.1 \%(\mathrm{M}=40.8)$. Meanwhile, the control group students got the highest average rating in $44.6 \%$ Interest Career in the field $(\mathrm{M}=34.3)$ and the lowest in Interest increased learning time in $32.6 \%$ cultural values $(\mathrm{M}=32.8)$.

Table 8 Independent sample t-test for attitudes to cultural values

\begin{tabular}{|c|c|c|c|c|c|c|}
\hline & \multirow[t]{2}{*}{$\mathbf{T}$} & \multirow[t]{2}{*}{ df } & \multirow{2}{*}{ Mean } & \multirow{2}{*}{ Std.Deviation } & \multicolumn{2}{|c|}{$\begin{array}{c}\text { 95\% confidence } \\
\text { interval }\end{array}$} \\
\hline & & & & & Lower & Upper \\
\hline \multirow{2}{*}{$\begin{array}{l}\text { Attitudes towards } \\
\text { cultural values }\end{array}$} & 18.473 & 68 & 3.0906 & .14321 & 18.236 & .6120 \\
\hline & 18.473 & 128.067 & 2.2033 & .20015 & 17.935 & .8615 \\
\hline
\end{tabular}

From table 8 it can be seen that the value is obtained ( $t$ count) with the value of $t$ table. The t-table value can be found in table $t$ with a significance value of 0.025 (2-sided test) with degrees of freedom (df) 68. In this study, the results for $t$ table are 1.97658. While for the value of $t$ count can be seen in table 7. (column t) which is 18.473. The hypothesis testing criteria is that there is a rejection value of $\mathrm{H}_{0}$ (Cramer, 2003). So, it can be concluded that there is a significant difference in attitudes towards the cultural values of students between the control classes taught using traditional teaching materials and experimental classes using the inquiry-based ethnoconstructivism module. It can be seen from table 7 that the average value of student interest is 3.0906, which means it can improve the attitude of students in learning cultural values.

\section{Discussion}

This study supports the constructivist theory framework proposed by Widodo (2007) that concepts can be constructed with cultural values. From the results of questionnaire data processing on indicators of interest increasing learning time values Inquiry-based (experiment) categorized well with $47.3 \%$ and those who did not (controls) categorized enough with $32.6 \%$. The student attitude category on this indicator proves that only a few students are interested in expanding their time in learning cultural values. Based on the results of interviews with students who categorize attitudes it is known that when they finish school they learn cultural values at home individually or in groups and ask friends about material that is not yet understood. This can be seen from the interview show I study again at home if I don't understand at school, but only occasionally when I feel the material needs to be reviewed. But if I am still confused about studying at school, then I will go to the library and ask the teacher or friend during recess or when there are empty hours. The pleasure of students in learning cultural values will influence students to increase the time to learn cultural values. Syahrin et al (2019); Bulunuz, (2015) "The interest in spending time in students' cultural values is an important attitude because interest or interest in cultural values can make students serious about learning. Suastra (2010); Kirom (2018) "Students' interest in learning cultural values, therefore, may be important in predicting their long-term persistence in learning". A high positive attitude towards an interest in improving and influencing learning outcomes. Manurung, (2012); Zinnurain \& Muzanni (2018) "Students who are interested in increasing learning time about cultural values will influence the achievement and learning outcomes of culture".

From the results of questionnaire data processing on indicators of interest increasing learning time values Inquiry-based (experiment) categorized well with $50.6 \%$ and those who did not (controls) categorized enough with $39.3 \%$. Students who approve it can put themselves like humanists with all kinds of life and habits. The results of interviews that have been conducted show that all scientists have normal lives like humans who work and have families. The following are the results of the interview. I know, Like Sujiwo Tejo, Shakespeare and Michelangelo. For their lives, maybe the same as people in general. Eat, sleep, work, research on the laboratory as possible. I also believe that a Buddhist is also the same as others. if the cultural experts say they cannot have a family or a happy marriage, there must be many who avoid becoming cultural. From the results of this 
interview, students can imagine the daily life of the humanist and assume that a humanist also has a normal life side like humans in general. This shows that, students have the view that the humanist is a normal person, does not accuse the humanist of being silent and unable to socialize so that they are kept away from the lives of the surrounding community. This was confirmed by students who began to think of humanists as realistic people (Leblebicioglu, et al, 2011; Astalini et al, 2018), inventors and problem solvers, did many things, unique, worked as thinkers (Balcin and Ergun, 2018). Cultural humanity, assesses how students see culture and place themselves as students of art or culture.

From the results of questionnaire data processing on indicators of interest career in the field of values Inquiry-based (experiment) categorized well with $47.1 \%$ and those who did not (controls) categorized enough with $44.6 \%$. Based on the results of interviews with students who are categorized as sufficient attitudes, it is known that when they are adults they want to work in the field of Culture. However, they are interested in a career at Cultural Subjects. I want to have a career in a cultural subject, but not a teacher, because being a teacher is a difficult job. Interest and attitude are the main keys to increasing student participation in a career in the field of culture. To be able to improve students in a career in the field of Cultural Subjects it is necessary to pay attention to the interests of those whose interests greatly influence career and personal life achievements (Arslan, 2015). The interest in culture possessed by students at the secondary school level influences careers related to culture in the future (Juan, 2016). In addition to interest, having a positive attitude toward students in studying the Eye Cultural lessons also affect students' careers in the cultural field. Having positive attitudes and interests in culture Subjects can cause future career interest in the cultural field Subjects will increase (Welch, 2010). The interest in careers in cultural subjects is one of the good capital for improving learning outcomes in Cultural Subjects. Careers in culture cause students to be attracted to cultural subject learning that will affect achievement and learning outcomes (Rodger Bybee, 2009). Students who want to pursue a career in the field of culture will broaden their horizons and curiosity towards the culture itself.

Based on the data obtained from the implementation of the inquiry learning model assisted by the ethnoconstructivism module, it can be seen that the use of modules is effective in increasing attitudes towards the cultural values of the students themselves. If students have an attitude to good cultural values it will have a positive impact on student learning outcomes. Where learning is a characteristic of cognitive, affective and psychomotor, as indicators that act relatively stable for learning that are interconnected and react to the learning environment (Keefe, 1990). And attitudes have factors that can influence social and internal conditions within themselves (Craker, 2006). Through learning to use products from information and communication technology various multimedia services can be easily transferred, such as audio, video, high-resolution graphics so that the thought process can lead to thinking. Wongwatkit et al. (2017); Zheng, et al. (2018) developed a personalized mobile learning system to support guided inquiry learning activities for secondary school students. They found that student learning attitudes and attitudes increased significantly.

\section{CONCLUSIONS AND SUGGESTIONS}

It can be seen that the results of student attitudes to cultural values show a good category after being given an inquiry-based learning model assisted by ethnconstructivism modules. On the results of attitudes on students 'cultural values and students' critical thinking skills for the control class using traditional teaching materials there were significant differences with the experimental class using the inquiry learning model assisted by ethnoconstructivism modules who were in the superior experimental class because they used a module-assisted inquiry learning model ethnoconstructivism with $t$ test score 18,473 on the attitudes of student cultural values. According to the results, it is recommended that pre-service teachers need to be given the opportunity to develop direct experiences and thoughts in cultural activities. The lecturers must utilize the inquiry learning model assisted by the ethnoconstructivism module to develop various learning skills and attitudes from students for life.

\section{REFERENCES}

Aktekin, N. C. (2019). Critical Friends Group (CFG): Inquiry-Based Professional Development Model for Turkish EFL 
Teachers. Eurasian Journal Educational Research. 19(81), 1-20. DOI: 10.14689/ejer.2019.81.1

Arslan, N. I. (2015). High school students' educational and career interest (sciencetechnology- mathematics) and career adaptabilities. Australian Council for Educational Research, 24(3), 166-172. ttps://doi.org/10.1177/10384162155946 33

Astalini., Kurniawan, D. A., Perdana, R., \& Kurniasari, D. (2018). "Identification of Student Attitudes toward Physics Learning at Batanghari District High School". The Educational Review, USA, 2(9), 475-484. http://dx.doi.org/10.26855/er.2018.09.00 3

Astalini, A., Kurniawan, D. A., Perdana, R., \& Pathoni, H. (2019). Identifikasi Sikap Peserta Didik terhadap Mata Pelajaran Fisika di Sekolah Menengah Atas Negeri 5 Kota Jambi. UPEJ Unnes Physics Education Journal, 8(1), 34-43. https://doi.org/10.15294/upej.v8i1.2951 0

Astalini, Kurniawan, D. A., Perdana, R., \& Kurniawan, W. (2019). Identification Attitudes of Learners on Physics Subjects. EST Journal of Educational Science and Technology, 5(1), 39-48. https://doi.org/10.26858/est.v5i1.8231

Astalini, Kurniawan, D. A., Perdana, R., \& Pathoni, H. (2019). Characteristic of Students' Attitude to Physics In Muaro Jambi High School. Humanities \& Social Science Research. 7(2). 91-99. https://doi.org/1018510/hssr.2019.7210

Aybek, B., \& Aslan, S. (2016). An Analysis of the Units "I'm Learning my Past" and "The Place Where We Live" in the Social Studies Textbook Related to Critical thinking Standars. Eurasian Journal Educational Research. 16(65), 35-54. DOI: 10.14689/ejer.2016.65.03

Balcin, M, D., and Ayşegü, E. (2018). Secondary School Students' Perceptions and Attitudes About Scientists. European Journal of Education Studies, 4(4), 66-93. DOI: 10.5281/zenodo. 120698
Bulunuz, M. (2015). The Role of Playful Science in Developing Positive Attitudes Towards Teaching Science in a Science Teacher Preparation Program. Eurasian Journal Educational Research. 58, 67-88. http://dx.doi.org/10.14689/ejer.2014.58. 2

Departemen Pendidikan Nasional, 2003. Undang-Undang Nomor 20 Tahun 2003, Tentang Sistem Pendidikan Nasional, Jakarta: Depdiknas.

Cetin, Y., Mirasyedioglu, S., \& Cakiroglu, E. (2019). An Inquiry into the Underlying Reasons for the Impact of Technology Enhanced Problem-Based Learning Activities on Students' Attitudes and Achievment. Eurasian Journal Educational Research. 79, 191-208. DOI: 10.14689/ejer.2019.79.9

Christidou, V. (2011). Interest, Attitudes and Images Related to Science: Combining Students' Voices with the Voices of School Science, Teachers, and Popular Science. International Journal of Environmental and Science Education, 6(2), 141-159. https://files.eric.ed.gov/fulltext/EJ94484 6.pdf

Cohen, L., Manion, L., \& Morrison, K. (2005). Research Methods In Education : Routledge.

Colak, E. (2017). “Teachers' Experiences in a Professional Learning Community on The Constructivist Lesson Planning: A Case Study Among Primary School Teachers". Education and Science. 42(190). 189-209. DOI: 10.15390/EB.2017.6911

Cramer, D. (2003). Advanced quantitative data analysis. McGraw-Hill Education (UK).

Craker, D. E. ( 2006). Attitudes Toward Science Of Students Enrolled In Introductory Level Science Courses At UW-La Crosse. UW-L Journal Of Undergraduate Research IX, 9, 1-6. https://www.uwlax.edu/urc/juronline/pdf/2006/craker.pdf

Creswell, J, W. 2012. Educational Research: Planning, Conducting, And Evaluating 
Quantitative And Qualitative Research. New York: Pearson

Darmaji., Kurniawan, D. A., Parasdila, H., \& Irdianti. (2018). Description of Science Process Skills' Physics Education Students at Jambi University in Temperature and Heat Materials. The Educational Review, USA. 2(9): 485498.

http://dx.doi.org/10.26855/er.2018.09.00 4

Esther Agunbiade, K. N. (2017). An Exploratory Study of the Relationship between Learners' Attitudes Towards Learning Science and Characteristics of an Afterschool Science Club. African Journal of Research in Mathematics, Science and Technology Education, 21(3), 271-281. https://doi.org/10.1080/18117295.2017. 1369274

Gillette, C. M. (2017). Consideration of Problem-Based Learning in Athletic Training Education. Athletic Training Education Journal, 12(3), 195-201. https://doi.org/10.4085/1203195

Guido, R. M. (2013). Attitude and Motivation towards Learning Physics. International Journal of Engineering Research \& Technology, 2(11), 2087-2094. https://www.ijert.org/research/attitudeand-motivation-towards-learningphysics-IJERTV2IS1 10659.pdf

Hidayat, H., Kusumaningrum, I., \& Mardin, A. (2017). Needs Analysis of Entrepreneurships Pedagogy of Technology and Vocational Education with Production Base Learning Approach in Higher Education. International Journal on Advanced Science, Engineering and Information Technology, $\quad$ 7(5), 1701-1707. http://dx.doi.org/10.18517/ijaseit.7.5.15 10

Juan, A. R. (2016). Does it matter whether students enjoy learning science? Exploring student attitudes towards science in South Africa. Human Sciences Reseach Council, 1-6.

Leblebicioglu,G., Duygu, M., Esra, Y., Cetin, P. S. (2011). The effect of informal and formal interaction between scientists and children at a science camp on their images of scientists. Science Education International, 22(3), 158-174. https://eric.ed.gov/?id=EJ941681

Keefe, J. \& Ferrell, B. (1990). Developing a defensible learning style paradigm , Educational Leadership, 48(2), 57- 61.

Kirom, S. (2018). Penguatan Karakter Diri Melalui Pembelajaran Drama Berbasis Kearifan Lokal Pada Mahasiswa. Jurnal Inspirasi Pendidikan. 8(1), 40-52. DOI: https://doi.org/10.21067/jip.v8i1.2 243

Kurniawan, D, A., Astalini., \& Anggraini,L. (2018). Evaluasi Sikap SMP Terhadap IPA di Kabupaten Muaro Jambi. Jurnal Ilmiah Didaktika: Media Ilmiah Pendidikan dan Pengajaran. 19(1), 123139.

http://dx.doi.org/10.22373/jid.v19i1.419 8

Kunnari, I., \& Ilomäki, L. (2016). Reframing teachers' work for educational innovation. Innovations in Education and Teaching International, 53(2), 167178. https://doi.org/10.1080/14703297.2014. 978351

Kerlinger, F. N. (2014). Foundations of behavioral research. Yogyakarta: Gadjah Mada

Kyriakides, L. \& Creemers, B. P. M. (2008). "Using a Multidimensional Approach to Measure the Impact of Classroom Level Factors upon Student Achievement: a Study Testing the Validity of the Dynamic Model". School Effectiveness and School Improvement, 19(2), 183205.

https://doi.org/10.1080/0924345080204 7873

Manurung, R. T. (2011). Pengajaran Bahasa Yang Berkarakter Kebangsaan dan Berprespektif Multibudaya dalam Era Globalisasi. Sosiohumaniora. 13(2), 235-242.

https://doi.org/10.24198/sosiohumaniora .v13i2.5519

Rabgay, T. (2018). The Effect of Using Cooperative Learning Method on Tenth Grade Students' Learning Achievement 
and Attitude towards Biology. International Journal of Instruction, 11(2), 265-280. https://doi.org/10.12973/iji.2018.11218a

Rodger Bybee, B. M. (2009). PISA 2006: An Assessment of Scientific Literacy. Journal Of Research In Science Teaching, 46(8), 865-883. https://doi.org/10.1002/tea.20333

Seferoglu, S.S., 2004. Attitudes to teachers' of the teacher candidates. In XII. National Congress of Education Sciences (pp. 413-425).

Simsek, P., \& Kabapınar, F. (2010). The effects of inquiry-based learning on elementary students' conceptual understanding of matter, scientific process skills and science attitudes. Procedia-Social and Behavioral Sciences, 2(2), 1190-1194. https://doi.org/10.1016/j.sbspro.2010.03. 170

Suastra. (2010). Model Pembelajaran Sains Berbasis Budaya Lokal Untuk Mengembangkan Kompetensi Dasar Sains dan Nilai Kearifan Lokal di SMP. Jurnal Pendidikan dan Pengajaran. 43(2), $\quad$ 8-16. http://dx.doi.org/10.23887/jppundiksha. v43i1.1697

Sofanudin, A., \& Rokhman, F. (2016). QualityOriented Management of Educational Innovation at Madrasah Ibtidaiyah. Journal of Education and Practice, $7(27)$, 176-180. https://eric.ed.gov/?id=EJ1115847

Syahrin, A., Dawud., Suwignyo, H., \& Priyatni, E. T. (2019). Creative Thinking Patterns In Student's Scientific Works. Eurasian Journal of Education Research. 81, 2136. DOI: 10.14689/ejer.2019.81.2

Tezer, M., Kan, \& Bas. (2019). Content analysis of master's degree and doctorate theses where social skills training is approached, International Journal of Cognitive Research in Science, Engineering and Education (IJCRSEE), 7(1), 43-49. doi:10.5937/IJCRSEE1901043T

Trumper, Ricardo. 2006. Factors Affecting Junior High School Students' Interest in Physics. Journal of Science Education and Technology, 15(1), 47-58. https://doi.org/10.1007/s10956-0060355-6

Welch, A. G. (2010). Using the TOSRA to Assess High School Students' Attitudes toward Science after Competing In the FIRST Robotics Competition: An Exploratory Stud. Eurasia Journal of Mathematics, Science \& Technology Education, 187-197. https://doi.org/10.12973/ejmste/75239

Widodo, A. (2007). Konstruktivisme dan Pembelajaran Sains. Jurnal Pendidikan dan Kebudayaan, 13(64), 91-105.

Wulandari, S. (2013). Inquiry-based active learning: the enhancement of attitude and understanding of the concept of experimental design in biostatics course. Asian Social Science, 9(12), 212. http://dx.doi.org/10.5539/ass.v9n12p212

Wongwatkit, G., Panjaburee, P. and Srisawasdi, N. (2017). 'A proposal to develop a guided-inquiry mobile learning with a mastery learning mechanism for improving students' learning performance and attitudes in Physics', Int J. Mobile Learning and Organisation, 11(1), pp.63-86. https://doi.org/10.1504/IJMLO.2017.08 0898

Zheng, L., Li, X., Tian, L. and Cui, P. (2018). 'The effectiveness of integrating mobile devices with inquiry-based learning on students' learning achievements: a metaanalysis', Int. J. Mobile Learning and Organisation, 12(1), pp.77-95. https://doi.org/10.1504/IJMLO.2018.08 9238

Zinnurain., \& Muzanni, A. (2018). Pengembangan Buku Ajar Berbasis Kearifan Lokal Pada Siswa Kelas V Sekolah Dasar. Julnal Ilmiah IKIP Mataram. 4(2), 63-69. http://jurnal.ikipmataram.ac.id/index.ph $\mathrm{p} / \mathrm{jiim} /$ article/view/192 